\title{
Perbandingan Keamanan dan Konversi Tuberkulin dari Vaksin BCG Strain Moskow dan Vaksin BCG Strain Pasteur pada Bayi
}

\author{
Ni Putu Siadi Purniti, ${ }^{*}$ Novilia Sjafri Bachtiar, ${ }^{* *}$ Ida Bagus Subanada, ${ }^{*}$ Ayu Setyorini, ${ }^{*}$ Putu Junara Putra, ${ }^{*}$ Wayan Gustawan, ${ }^{*}$ \\ IGA Trisna Windiani, ${ }^{*}$ Julitasari S, ${ }^{* * *}$ Syafriyal, ${ }^{* * *}$ Rini Mulia Sari** \\ * Bagian Ilmu Kesehatan Anak Fakultas Kedokteran Universitas Udayana/RSUP Sanglah, **PT Bio Farma, ***Komnas KIPI
}

Latar belakang. Pemberian vaksin BCG pada bayi masih menjadi kebijakan pemerintah Indonesia dan WHO.

Tujuan. Membandingkan keamanan dan konversi tuberkulin vaksin BCG strain Moskow dengan strain Pasteur.

Metode. Tergabung dalam penelitian ini 220 bayi 0-1 bulan, kelompok A menerima vaksin BCG strain Pasteur, dan kelompok

B menerima strain Moskow dengan randomisasi tersamar tunggal. Reaksi lokal dan sistemik yang timbul diamati hingga 30 hari pasca imunisasi. Uji tuberkulin dilakukan pada hari ke-90 pasca imunisasi, dengan pembacaan 48-72 jam kemudian.

Hasil. Terdapat 205 anak berhasil menyelesaikan studi. Pembesaran kelenjar getah bening ditemukan pada kedua kelompok, masing-masing 2 bayi, yang sembuh sendiri tanpa pengobatan. Tidak ditemukan kejadian ikutan pasca imunisasi serius karena vaksin BCG. Jumlah bayi yang mempunyai jaringan parut dan konversi tuberkulin tidak berbeda signifikan, $p=0,578$ dan $p=0,205$ $(\mathrm{p} \geq 0.05)$.

Kesimpulan.Vaksin BCG strain Pasteur dan strain Moskow mempunyai profil keamanan dan konversi tuberkulin yang relatif sama. Sari Pediatri 2015;17(3):169-74.

Kata kunci: BCG, keamanan, konversi tuberkulin

\section{Safety and Tuberculin Conversion following BCG Moscow Strain Vaccina- tion compared to BCG Pasteur Strain in Indonesian Infants}

Ni Putu Siadi Purniti, ${ }^{*}$ Novilia Sjafri Bachtiar, ${ }^{* *}$ Ida Bagus Subanada,* Ayu Setyorini, ${ }^{*}$ Putu Junara Putra, ${ }^{*}$ Wayan Gustawan, ${ }^{*}$ IGA Trisna Windiani, ${ }^{*}$ Julitasari $S,{ }^{* * *}$ Syafriyal, ${ }^{* * *}$ Rini Mulia Sari**

Background. BCG vaccination for infants is still recommended by WHO and Immunization Program in Indonesia.

Objective. To compare the safety and the tuberculin conversion following BCG vaccination with Moscow Strain compared to Pasteur Strain.

Method. Total of 220 infants aged 0-1 month were enrolled into this study, and were randomized into two groups: Group A that received BCG Pasteur Strain while group B received BCG Moscow Strain. Local reactions and systemic events were monitored within 30 days following immunization. Tuberculin test was done at day $90^{\text {th }}$ day and was "read"/evaluated within 48-72 hours.

Result. About 205 infants completed the study. Regional limphadenitis were found in both groups, 2 cases in each group, and recovered with out any medication. No serious adverse event was found to be related with BCG vaccines in both groups. Infants with BCG scar and tuberculin conversion were not significantly different in both groupswith $\mathrm{p}=0.578$ and $\mathrm{p}=\mathbf{0 . 2 0 5}$ ( $\mathrm{p} \geq 0.05$ respectively).

Conclusion. BCG vaccines from Pasteur strain and Moscow strain are relatively similar in term of safety and tuberculin conversion. Sari Pediatri 2015;17(3):169-74.

Keywords: BCG, safety, tuberculin conversion

Alamat korespondensi: Dr. Putu Siadi Purniti, SpA(K). Bagian Ilmu Kesehatan Anak Fakultas Kedokteran Universitas Udayana/RSUP Sanglah. Jl. Pulau Nias, Denpasar. Tel. +62-361-227911 E-mail: siadi_purniti@idai.or.id 
S alah satu penyakit yang dapat dicegah dengan imunisasi adalah tuberkulosis, meskipun protektivitasnya mempunyai rentang yang sangat lebar, antara 20\% hingga 80\%. ${ }^{1}$ Sampai saat ini, infeksi tuberkulosis (TB) masih menjadi masalah kesehatan dan diperkirakan sepertiga penduduk dunia terpapar dengan bakteri tuberkulosis setiap tahunnya. Secara global, Mycobacterium tuberculosis menginfeksi kurang lebih 9 juta kasus baru dengan 1,7 juta kematian setiap tahunnya, 200.000 di antaranya berhubungan dengan penderita HIV. Di beberapa negara maju, peningkatan kasus baru TB sejalan dengan meningkatnya jumlah penderita HIV..$^{2-4}$ Menurut data WHO tahun 2014, Asia Tenggara adalah penyumbang terbanyak kasus tuberkulosis (39\%), di India saja sudah 26\%.5

Saat ini, Indonesia berada pada peringkat ke lima negara dengan beban TB tertinggi di dunia. Estimasi prevalensi TB semua kasus adalah 660,000 (WHO, 2010) dan estimasi insidensi berjumlah 430,000 kasus baru per tahun. Jumlah kematian akibat TB diperkirakan 61,000 kematian per tahunnya. ${ }^{6}$

Respon imun yang dihasilkan setelah imunisasi BCG tidak sepenuhnya dipahami. Namun demikian, WHO tetap merekomendasikan pemberian vaksin BCG 1 dosis pada semua bayi segera setelah lahir pada daerah dengan beban penyakit tuberkulosis yang tinggi, seperti di Indonesia.?

Sebagian besar studi lapangan menunjukkan bahwa vaksin BCG efektif mencegah penyakit tuberkulosis yang berat seperti meningitis dan tuberkulosis diseminata. Hasil ini menunjukkan bahwa BCG berperan dalam mencegah penyebaran kuman tubekulosis melalui darah. Dengan demikian, vaksin BCG bukan mencegah penyakit tuberkulosis, tetapi menahan pertumbuhan fokus perimer pada paru dan kelenjar getah bening dan mencegah penularan secara limfohematogenus. ${ }^{2}$

Kebutuhan vaksin BCG program imunisasi di Indonesia dipenuhi oleh Bio Farma untuk mengantisipasi peningkatan kebutuhan. Sementara produksi tidak dapat ditingkatkan maka Bio Farma perlu mendatangkan vaksin BCG dari perusahaan vaksin di India, Serum Institute of India (SII). Vaksin tersebut adalah vaksin yang sudah mendapat registrasi di negara asalnya India. Namun, karena akan digunakan pada program imunisasi nasional, perlu dilakukan penelitian untuk mengetahui efek vaksin pada bayi di Indonesia. Pada penelitian ini akan dievaluasi reaksi lokal dan sistemik, kejadian ikutan pasca imunisasi (KIPI) serius, serta mengamati konversi tuberkulin yang terjadi pada masing-masing kelompok.

\section{Metode}

Penelitian intervensi dilakukan di Departemen Ilmu Kesehatan Anak FK UNUD/ RSUP Sanglah, pada periode Januari-Juli 2012. Penelitian mendapat persetujuan etik dari Komite Etik Unit Penelitian dan Pengembangan Fakultas Kedokteran Universitas Udayana, Nomor:620/Skrt/VIII/2011. Subjek penelitian terdiri atas 220 bayi usia 0-1 bulan yang lahir di RS Sanglah. Bayi yang lahir cukup bulan, dengan partus normal, sehat, orang tua menyetujui dan menandatangani formulir informed consent akan mendapat nomor inklusi dan kelompok random. Kelompok A menerima vaksin BCG strain Pasteur (Bio Farma), dan kelompok B menerima vaksin BCG strain Moskow (SII) dengan desain blok randomisasi dan tersamar tunggal.

Setiap subjek mendapat 1 dosis vaksin BCG sesuai grup randomnya yang diberikan secara intradermal. Pengamatan terhadap reaksi lokal dan sistemik yang timbul dilakukan pada 24 jam (K-1), 7 hari (K-2), 30 hari (K-3) pasca imunisasi. Tambahan pengamatan reaksi lokal dilakukan pada 60 (K-4) dan 90 (K-5) hari pasca imunisasi. Kejadian ikutan pasca imunisasi serius (KIPI serius) diamati hingga 30 hari pasca imunisasi. Uji tuberkulin dilakukan pada 90 hari pasca imunisasi, dan reaksi yang timbul diamati setelah 48-72 jam. Semua hasil yang diperoleh dibandingkan antara kelompok A dan B. Perbedaan proporsi akan dibandingkan dengan chi-square atau eksak Fisher.

\section{Hasil}

Terdapat 205 bayi berhasil menyelesaikan penelitian ini. Tabel 1 memperlihatkan bahwa pada kedua kelompok, subjek berjenis kelamin laki-laki lebih banyak dari pada perempuan. Jumlah total subjek untuk masing-masing kelompok yang berhasil menyelesaikan rangkaian kegiatan hingga selesai berjumlah hampir berimbang, 102 pada kelompok A dan 103 kelompok B. Limabelas subjek tidak berhasil menyelesaikan pengamatan akibat pindah alamat, berkunjung ke tempat lain dalam waktu yang lama, dan alamat rumah yang tidak jelas. Semua subjek yang tidak datang dilakukan pelacakan untuk memastikan bahwa ketidak hadirannya bukan karena 
Tabel 1 Distribusi subjek menurut jenis kelamin

\begin{tabular}{|c|c|c|c|c|c|c|}
\hline \multirow{3}{*}{ Jenis kelamin } & \multicolumn{4}{|c|}{ Grup } & \multirow{2}{*}{\multicolumn{2}{|c|}{ Total }} \\
\hline & \multicolumn{2}{|c|}{ A } & \multicolumn{2}{|c|}{$\mathrm{B}$} & & \\
\hline & $\mathrm{n}$ & $\%$ & $\mathrm{n}$ & $\%$ & $\mathrm{n}$ & $\%$ \\
\hline Perempuan & 46 & 45.1 & 42 & 40.8 & 88 & 42.9 \\
\hline Laki-Laki & 56 & 54.9 & 61 & 59.2 & 117 & 57.1 \\
\hline Total & 102 & 100 & 103 & 100 & 205 & 100.0 \\
\hline
\end{tabular}

efek samping vaksin.

Pada pengamatan reaksi lokal yang timbul dalam 30 menit, hanya terjadi kemerahan 3\% pada kelompok $\mathrm{B}$, sedangkan pada kelompok A tidak ada timbul reaksi lokal cepat.

Gambar 1 memperlihatkan reaksi lokal berupa kemerahan terbanyak timbul pada kunjungan ke-4, yaitu 60 hari pasca imunisasi $70(68,6 \%)$ subjek pada kelompok A dan 82 (79,6\%) subjek pada kelompok B. Pola yang mirip juga terjadi pada pengerasan jaringan lunak.

Gambar 2 memperlihatkan gambaran keropeng pada bekas tempat suntikan menurut kunjungan terus meningkat, dan mencapai puncaknya pada kunjungan ke-5, yaitu 62 (60\%) subjek pada kelompok A dan 77 (75\%) pada kelompok B. Jaringan parut juga menunjukkan pola yang sama dengan kejadian keropeng.

Jaringan parut mempunyai pola kejadian yang sama dengan keropeng dengan kejadian terbanyak timbul pada kunjungan ke-5, yaitu $68(66,6 \%)$ subjek pada kelompok A dan $65(63,1 \%)$ pada kelompok B. Angka ini tidak berbeda secara bermakna dengan nilai $p=0,578$. Kejadian lokal lainnya adalah pembesaran kelenjar getah bening.

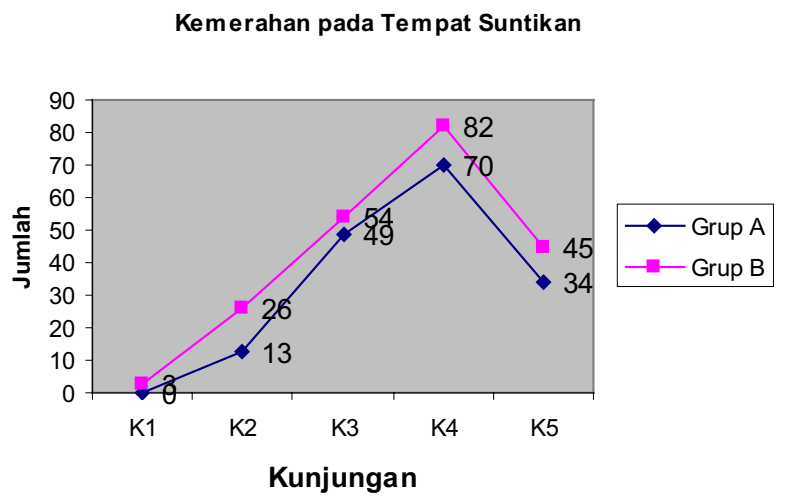

Gambar 1. Jumlah kemerahan pada tempat suntikan menurut kunjungan

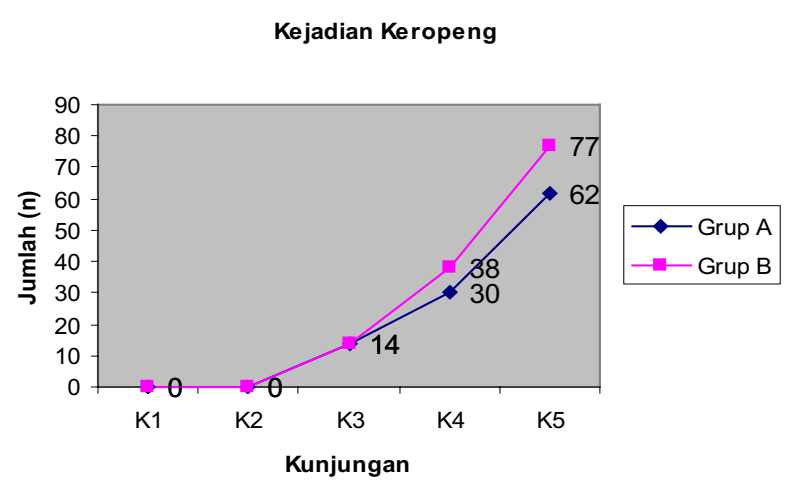

Gambar 2. Gambaran kejadian keropeng menurut kunjungan

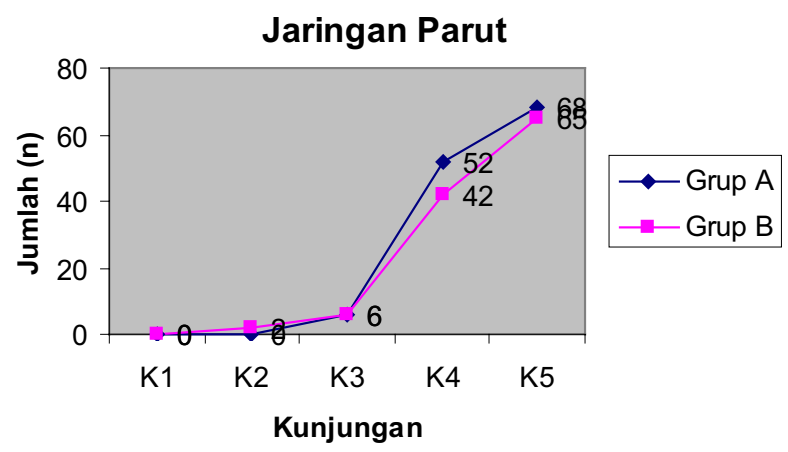

Gambar 3. Gambaran kejadian jaringan parut menurut kunjungan

\section{Pembesaran kelentah getah bening regional}

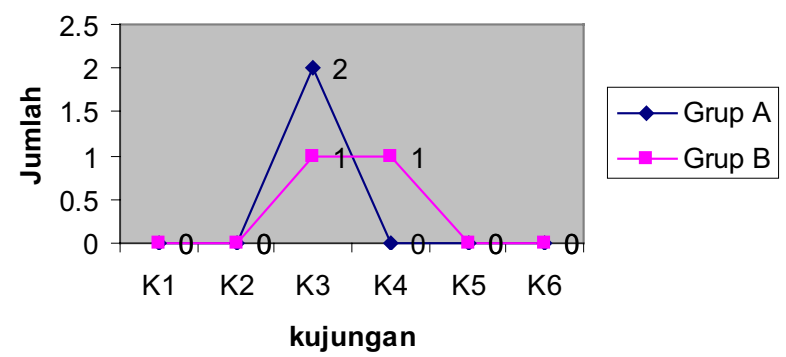

Gambar 4. Pembesaran Kelenjar Getah Bening Menurut Kunjungan 
Tabel 2. Distribusi subjek menurut hasil uji tuberkulin

\begin{tabular}{lcccccc}
\hline & \multicolumn{4}{c}{ Kelompok } & \multicolumn{2}{c}{ Total } \\
\cline { 2 - 6 } Hasil tes tuberculin K6 & \multicolumn{3}{c}{$\mathrm{A}$} & $\mathrm{n}$ & $\mathrm{B}$ & \multicolumn{2}{c}{} \\
\cline { 2 - 7 } & $\mathrm{n}$ & $\%$ & $\mathrm{n}$ & $\%$ & $\mathrm{n}$ & $\%$ \\
\hline Negatif & 77 & 75.5 & 73 & 70.9 & 150 & 73.2 \\
Positif & 25 & 24.5 & 30 & 29.1 & 55 & 26.8 \\
Total & 102 & 100 & 103 & 100 & 205 & 100.0 \\
\hline
\end{tabular}

Kejadian tertinggi pada kelompok A adalah saat kunjungan ke-3, yaitu 2 (2\%) kasus pada kelompok A dan 1 pada kunjungan ke-3 dan ke-4 pada kelompok B. Pembesaran kelenjar getah bening bersifat regional, masing-masing pada ketiak kanan, leher kanan (kelompok A), dan leher (kelompok B). Pembesaran kelenjar getah bening tidak berlangsung lama, paling lama hilang dalam waktu seminggu.

Tidak ditemukan reaksi sistemik pasca imunisasi BCG, seperti osteitis, osteomyelitis, maupun diseminasi BCG. Uji tuberkulin dilakukan pada kunjungan kelima (K-5).

Jumlah subjek yang mengalami konversi tuberkulin adalah 24,5\% untuk kelompok A dan 29,1\% kelompok B. Berdasarkan hasil analisis statistik dengan interval kepercayaan $95 \%$ didapat hasil $\mathrm{p}=0,205$ dengan perbedaan rerata (mean difference) adalah antara 2,287 sampai 0,495 . Karena nilai p $(0,205)>0,05$, disimpulkan tidak terdapat perbedaan bermakna antara reaksi tuberkulin yang muncul pada kunjungan ke-6 (enam).

\section{Kejadian ikutan pasca imunisasi serius}

Selama pengamatan terdapat 11 kejadian ikutan pasca imunisasi serius. Adapun KIPI serius yang terjadi tidak tercatat sebagai KIPI vaksin BCG, baik pada literatur maupun pada leaflet. Semua diagnosis disertai dengan hasil pemeriksaan penunjang yang mendukung. Berdasarkan hasil analisis dan pemeriksaan penunjang, tidak satupun dari KIPI serius disebabkan oleh vaksin BCG. Semua kasus KIPI serius adalah ko-insidens dan berakhir dengan kesembuhan.

\section{Pembahasan}

Vaksin BCG dibuat dari Mycobacterium bovis yang dilemahkan dengan pasase dari kultur secara berulang pada medium yang mengandung gliserol, potongan kentang, dan kaldu sapi. Terdapat empat strain utama yang digunakan sekarang, antara lain strain Pasteur 1173 P2 yang digunakan di 14 negara, strain Denmark 1331 dan strain Glaxo 1077 yang berasal strain Denmark dan strain Tokyo 172. Meskipun strain vaksin BCG di dunia berasal dari satu induk yang sama, perlakuan yang berbeda di masing-masing laboratorium akan menghasilkan sifat strain yang berbeda. Berdasarkan uji pada hewan, strain Pasteur 1173 P2 dan strain Denmark 1331 merupakan strain yang termasuk kategori strain yang kuat, sedangkan strain Glaxo 1077 dan strain Tokyo 172 termasuk dalam kategori strain yang lemah. ${ }^{2,8}$

Pada 90\%-95\% penerima imunisasi BCG akan mengalami reaksi lokal yang dimulai dengan papula pada minggu kedua atau lebih. Kemudian mengalami ulserasi dan kemudian sembuh meninggalkan jaringan parut (skar). ${ }^{8,9}$ Limfadenitis supuratif dapat terjadi 100-1000/juta dosis. Reaksi sistemik yang pernah dilaporkan adalah osteitis (1-700/juta dosis) dan limfadenitis diseminata (1,56-4,29/juta dosis). ${ }^{8,9}$

Pada penelitian kami, 30 menit pasca imunisasi, tidak ditemukan adanya reaksi cepat yang berbahaya seperti syok anafilaktik. Reaksi cepat yang ditemukan pada kelompok B 3 bayi yang mengalami kemerahan pada tempat suntikan. Pada kunjungan hari ke-7 pasca imunisasi terdapat $12,7 \%$ pada grup A dan $25,2 \%$ grup $\mathrm{B}$ yang mengalami reaksi lokal berupa kemerahan. Meskipun kelompok B mengalami kemerahan hingga dua kali lebih banyak, kemerahan ini hanya selama 1-2 hari saja. Kemerahan meningkat hampir mendekati separuh subjek pada pengamatan hari ke-30 (K3), dan mencapai 68,6\%-79,6\% pada bulan kedua (K4), kemudian turun menjadi $33,3 \%$ dan $44,1 \%$ pada bulan ketiga.

Keropeng timbul pada kunjungan ketiga, yaitu pengamatan pada 30 hari setelah imunisasi, 13,7\% pada kelompok A dan 13,6\% kelompok B, meningkat menjadi $14,6 \%$ dan $18,5 \%$ pada bulan kedua dan 
meningkat menjadi $30,2 \%$ dan $37,6 \%$ pada bulan ketiga. Berdasarkan literatur, reaksi lokal yang terjadi pasca imunisasi BCG memang sangat lazim. Pada 90\%-95\% penerima imunisasi BCG akan mengalami reaksi lokal yang dimulai dengan papula pada minggu kedua atau lebih. Kemudian mengalami ulserasi dan sembuh dengan meninggalkan jaringan parut (skar). . $^{8-10}$ Gambaran tersebut sangat mirip dengan yang terlihat pada penelitian ini, umumnya reaksi lokal mulai setelah kunjungan kedua (hari ke-7). Gambaran kemerahan yang ditemukan paling banyak terjadi sekitar 70\%-82\% mendekati angka yang diperoleh menurut literatur. Bila dibandingkan dengan literatur, jumlah reaksi lokal yang tergolong ringan ini masih terjadi dalam batas normal, yaitu kurang dari $90 \%$ pada kedua kelompok vaksin.

Jaringan parut yang timbul pasca imunisasi antara kelompok A dan B terjadi hampir sama, 66,6\% pada kelompok A dan 63,1\% kelompok B. Berbeda pada penelitian sebelumnya oleh Tanuwidjaja $\mathrm{dkk}^{11}$ yang mendapatkan skar $97,8 \%$ pada kelompok yang menerima vaksin BCG strain Pasteur 1173P2 dan 93,9\% pada kelompok vaksin BCG strain Copenhagen 1331 yang dilakukan pada tahun 2001. Perbedaan tersebut disebabkan oleh beberapa faktor, misalnya usia bayi pada saat diimunisasi. Pada penelitian ini semua bayi diimunisasi pada usia kurang dari 7 hari, sedangkan pada penelitian Tanuwidjaja dkk dilakukan pada bayi yang lebih besar, dengan rata-rata usia $>24$ hari. Dengan demikian, kemampuan untuk menghasilkan jaringan parut juga akan lebih besar.

Faktor lain yang juga menyebabkan perbedaan ini adalah waktu pengamatan jaringan parut dilakukan setelah 6 bulan, mungkin saja terjadi jaringan parut akan semakin besar. Sementara pada penelitian ini pengamatan jaringan parut dilakukan pada bulan ketiga, yang ditemukan proses reaksi lokal masih berlangsung pada bulan ketiga pengamatan karena masih ditemukan kemerahan, pengerasan. dan pengumpulan nanah. Namun, jaringan parut yang dihasilkan pada kelompok A dan B tidak berbeda bermakna $\mathrm{p}=0,578$.

Pembesaran kelenjar getah bening (KGB) mulai terlihat pada kunjungan ketiga (pengamatan 8-30 hari) 2 subjek pada kelompok A dan 1 kelompok B, turun menjadi 1 anak pada pengamatan bulan kedua di kelompok B (subjek yang berbeda dari pembesaran KGB kunjungan sebelumnya). Pembesaran KGB yang terjadi sembuh dengan sendirinya karena pada kunjungan kelima tidak ditemukan lagi adanya subjek dengan pembesaran kelenjar getah bening. Tanuwidjaja $\mathrm{dkk}^{11}$ melaporkan 2 kasus pembesaran KGB pada kelompok yang menerima vaksin Bio Farma, yaitu pada 1 bulan pasca imunisasi. Hal tersebut mirip dengan gambaran yang ditemukan pada penelitian kami, baik untuk vaksin BCG produksi Bio Farma maupun vaksin BCG produksi SII. Pada penelitian lain, di Polandia, ditemukan kasus limfadenitis (pembesaran KGB) dengan jumlah yang cukup besar. Kasus limfadenitis ditemukan 42/64 (67,2\%) dari 109 kasus pasca vaksinasi BCG tahun 2003-2006 di Polandia dan 28/64 (43,8\%) memerlukan tindakan pembedahan. ${ }^{12}$ Dibandingkan dengan studi di Polandia ini, limfadenitis yang terjadi pada kedua kelompok A dan B sangat rendah.

Pada penelitian ini dilaporkan 11 kejadian ikutan pasca imunisasi serius. Namun, tidak satupun merupakan reaksi vaksin. Semuanya termasuk kasus dengan klasifikasi KIPI ko-insidens. Tidak ditemukan juga adanya reaksi serius pasca imunisasi BCG, seperti infeksi BCG diseminata, ataupun osteitis, dan osteomielitis.

Reaksi tuberkulin dilakukan pada hari ke-90 atau bulan ketiga. Pengamatan reaksi tuberkulin dibaca pada 48 jam pasca penyuntikan PPD. Pada penelitian ini reaksi tuberkulin ditemukan $24,5 \%$ pada kelompok A dan 29,1\% kelompok B. Bila dibandingkan dengan studi yang dilakukan oleh Tanuwidjaja dkk, pada tahun 2004, konversi tuberkulin ditemukan 52,7\%, 63,2\%, dan $74,2 \%$ pada bayi yang diberikan vaksin BCG pada usia 1,2, dan 3 bulan. Pada penelitian ini disimpulkan juga bahwa semakin dini bayi diberikan imunisasi BCG maka semakin kecil konversi tuberkulinnya. ${ }^{13}$ Hal tersebut dapat menjelaskan bahwa konversi tuberkulin pada penelitian ini lebih rendah karena bayi diimunisasi pada usia rata-rata $0-2$ hari. Dengan demikian, kemungkinan konversi tuberkulin akan lebih rendah dari $52,7 \%$. Selain usia, banyak faktor yang memengaruhi hasil uji tuberjulin, jenis PPD yang digunakan, dan status mikobakterium pada lingkungan. Bayi kurang dari 6 minggu umumnya menunjukkan hasil uji tuberkulin yang negatif. ${ }^{7} \mathrm{Hal}$ tersebut semakin memperkuat bahwa semakin muda usia dilakukannya uji tuberkulin maka akan semakin kecil angka konversinya.

\section{Kesimpulan}

Vaksin BCG strain Pasteur produksi Bio Farma dan vaksin BCG strain Moskow produksi SII menunjukkan 
profil keamanan dan konversi tuberkulin yang relatif sama.

\section{Daftar pustaka}

1. Galazka AM.WHO. Global programme for vaccines and immunization expanded programme on immunization. The immunological basis for immunization series. Geneva: Modul 5:1993; 1-12.

2. Smith KC, Orme IM, Starke JR. Tuberculosis vaccine. Vaccines. Edisi ke-5.USA: Saunders; 2008.h.857-86.

3. WHO. Acute respiratory infections. update September 2009:1-8. Diakses 10 November 2014. Diunduh dari: http://www.who.int/vaccine_reasearch.diseases/ari/en/index4. html. .

4. Corbett EL, Watt CJ, Walker N. The growing burden of tuberculosis:global trends and interactions with the HIV epidemic. Arch Intern Med 2003;163:1009-21.

5. WHO-SEARO. Tuberculosis control in South East Asia Region, Annual report 2014:1-99.

6. Departemen Kesehatan RI. Strategi nasional pengendalian TB di Indonesia 2010-2014. Depkes 2011.h.1-80.

7. WHO. Weekly epidemiological record. BCG Vaccine.
WHO Position Paper 2004;4:27-38.

8. WHO. Information sheet; observed rate if vaccine reactions Bacille Calmette-Guerin (BCG) vaccine. Geneva: WHO;2012.h.1-5.

9. WHO, Department of vaccines and biologicals. Supplementary information on vaccine safety. Geneva: WHO;2000.h.14-7.

10. Departemen Kesehatan RI. KOMNAS PP KIPI. Pedoman tatalaksana medik kejadian ikutan pasca imunisasi (KIPI) bagi petugas kesehatan. Jakarta: Edisi ke5. Depkes;2005.h.3-17.

11. Suganda Tanuwidjaja, Eddy Fadlayana. Kejadian Ikutan Pasca Imunisasi BCG Galur Copenhagen 1331 dan Pasteur 1173P2 pada bayi 0-2 bulan. Maj Kedokt Bandung 2002;34:74-81.

12. Gotebiowska M, Abdrzeiewska E, Stryiewska I. Adverse events following BCG vaccination in infants and children up tu 36 months of age. Przegi Epidemil 2008;62:71-5.

13. Tanuwidjaja S, Rusmil K, Fadlyana E, Dhamayanti M, Kartini H. Tes tuberkulin dan jaringan parut satu tahun setelah vaksinasi BCG yang dilakukan pada umur 0-2 bulan, laporan akhir. Bandung: FK UNPAD-Bio Farma;2004.h.1-25. 